Accepted: 17/02/2020, Reviewed: 15/06/2020, Published: 30/04/2021

\title{
EFFECTS OF FERMENTATION DURATION ON PHYSICOCHEMICAL AND ORGANOLEPTIC CHARACTERISTICS OF THREE AGARWOODS (Aquilaria) LEAVES TEA
}

\author{
Anisa Leksono, Erni Sofia Murtini* \\ Department of Agricultural Products Technology, FTP Brawijaya University Malang \\ JI. Veteran, Malang 65145 \\ ${ }^{*}$ Correspondence Author, Email: erni.murtini@ub.ac.id
}

\begin{abstract}
Aquilaria is one of the plant genus-producing agarwood. Aquilaria leaves have pharmacological effects which the potential to be processed into black tea. The aim of this study is to determine the effect of fermentation duration on physicochemical and organoleptic characteristics of Aquilaria leaves tea. This study employed a Completely Randomized Design with two factors; the plant species ( $A$. crassna, $A$. malaccensis, and $A$. subintegra) and fermentation duration ( 0 minutes, 70 minutes, and 90 minutes). Parameters analyzed including water content, total phenol, and antioxidant activity. Organoleptic tests were performed on the color, taste, and aroma of the brewed tea. The results summarized that $A$. subintegra had the highest total phenol and antioxidant activity, but the taste of the tea was not favored. A. crassna fermented 70 minutes and A. malaccensis fermented 0 minutes were the most preferred, but both have lower total phenol and antioxidant activity than $A$. subintegra.
\end{abstract}

Keywords: Aquilaria, Antioxidant activity, Organoleptic test, Tea, Total phenol

\section{INTRODUCTION}

Tea becomes one of the favorite beverages in the world community, including Indonesia. The popularity of tea rises due to its efficacy in improving body health. Most of the processed tea such as green tea and black tea, are made from Camelia sinensis. However, in recent years, several ingredients have appeared to serve as an alternative tea such as rosella tea, ginko tea, chamomile tea, mulberry tea, lotus tea, and agarwood tea (Adam, Lee, and Mohamed, 2017).

Agarwood tea is made from agarwood-producing plant leaves (Aquilaria spp.). The global trade name of an agarwood is known as aloeswood and eaglewood (Nasution, Batubara, and Surjanto, 2015). Agarwood or resin has high value with its characteristic of good aroma. The utilization of agarwood including for medical purposes, fragrance, religious activities within Buddhists, Jews, Christians, Muslims, and Hindus communities (Wyn and Anak, 2010). Agarwood essential oil has high price due to the great demand in the Middle Eastern countries; moreover, in general agarwood is processed into cosmetic products (Adam, Lee, and Mohamed, 2017). The production of agarwood can be sourced from more than 26 types of tree in the genus of Aquilaria, Aetoxylon, Gyrinops, and Wikstroemia (Bizzy, Faisal, and Setiabudidaya, 2011). In the genus of Aquilaria, agarwood is generated from $A$. malaccensis, $A$. agallocha, A. baillonii, A. crassna, A. hirta, A. rostrata, A. beccariana, $A$. cummingiana, A. filaria, A. khasiana, A. microcarpa, A. grandiflora, A. chinesis or $A$. Sinensis, A. borneensis, and A. Bancana plants (Blanchette and Beek, 2001). Aquilaria is originated from Asia, North India to Vietnam, and Indonesia (Blanchette and Beek, 2001).

The chemical components of Aquilaria leaves consist of phenolic, flavonoids, alkaloids, and Vitamin E. The flavonoid compounds of Aquilaria leaves tea have similar content as 
those in black tea such as epicatechin gallate and epigalocatechin gallate (Adam, Lee, and Mohamed, 2017). Those two compounds play an essential role in forming the taste and color of brewed black tea (Anggraini, 2017). Furthermore, according to Adam, Lee, and Mohamed (2017), Aquilaria leaves have pharmacological effects for health, which include antioxidant, anti-tumor, anti-cancer, analgesic, anti-arthritis, anti-inflammatory, anti-bacterial, anti-fungal, and anti-diabetic activity. According to its chemical compounds and health benefits, Aquilaria leaves become suitable to process into black tea. This idea was supported by a previous study that shows the best fermentation time of shoots of $A$. malaccensis which processed into black tea is within 70 minutes (Rahmadini, 2015).

The objective of this research is to obtain good quality leaves of species of Aquilaria which suitable to process into black tea. Therefore, the research used three different Aquilaria species: $A$. malaccensis, $A$. crassna, and $A$. subintegra with three fermentation times; 0,70 , and 90 minutes.

\section{METHODOLOGY}

\section{Materials}

The tea processing used ingredients namely Aquilaria shoots which are harvested from a total of 7 trees consisting of 3 trees of $A$. crassna, 2 trees of $A$. malaccensis, and 2 trees of $A$. subintegra. The leaves were firstly picked by trimming and cutting down the trees. The young leaves with a yellowish-green color were selected. If the young leaves are more than 5 pieces, then the maximum leaves to pick are 5 pieces, including the shoots. Other ingredients used were distilled water, Folin-Ciocalteu reagent, $\mathrm{Na}_{2} \mathrm{CO}_{3} 2 \%$, DPPH (2,2diphenyl-1-pycrylhydrazyl), methanol, and ethanol.

\section{Apparatuses}

This research used electric drying oven, withering basket, tray fermenter, and wooden rolling pin to roll the leaves, thermometer Lutron LM-8000, sieves with the size of 10,20 and 80 mesh, hot plate stirrer, vortex, desiccators, UV-vis spectrophotometer, and other supporting glassware.

\section{Research Methods}

This research was performed using 2 factors which plant species and fermentation arranged to follow a completely randomized design (CRD). Plant species are from Aquilaria genus namely $A$. crassna, $A$. malaccensis, and $A$. subintegra. The duration of the fermentation factor considered three different times of 0,70 , and 90 minutes.

\section{Research Phases}

Agarwood Tea Processing

The processes conducted in the research are including the phase of withering, kneading, fermentation, drying, and milling. The leaves picked were washed using clean water and then withered for 12 hours. After withering, the leaves of each type of Aquilaria were divided into 3 parts according to the total of fermentation treatments (enzymatic oxidation), namely 0 minutes, 70 minutes, and 90 minutes. The leaves were rolled (kneaded) for 5 minutes using a wooden rolling pin, and then fermented according to its treatment. After fermentation treatment completed, the leaves were wrapped in baking paper and then dried for 48 hours in the oven at $60^{\circ} \mathrm{C}$. The dried Aquilaria tea leaves were then reduced in size by grinding them into powder. The milling was performed for 1 minute using a dry spice blender for household use. The result of tea powder was used for analysis afterward. Dry tea test analysis includes chemical tests for water content, total phenol, and antioxidant activity, while organoleptic tests are performed for tea brewed water. 
Preparation of the Tea Sample Solution

Approximately $1 \mathrm{~g}$ of agarwood leaves tea powder was put into an Erlenmeyer glass and then brewed by adding $100 \mathrm{ml}$ of hot distilled water $\left(100^{\circ} \mathrm{C}\right)$. The agarwood tea sample was placed in a volumetric flask, left for 5 minutes, and then filtered using cotton. The filtered results (sample solution) were stored in an Erlenmeyer glass and were ready to be analyzed for its total phenol content and antioxidant activity.

\section{Analytical Procedures}

Determination of Particle Size and Water Content

Tea powder produced by grinding using blender was then weighed to obtain milled weigh and was sieved to know the powder particle size composition. Sieving was performed by three different sizes of sieve; mesh 10 , mesh 20 , and mesh 80 . The powder that passed through each sieve was weighed to determine the passing percentage. The percentage was calculated by the following formula.

Percentage of passing $(\%)=\frac{B 2}{B 1} \times 100$

Description:

B1 = milled powder weight (milled weight) $(\mathrm{g})$

$\mathrm{B} 2$ = passing powder weight $(\mathrm{g})$

The water content was calculated following the loss of sample weight heated at $105^{\circ} \mathrm{C}$ under SNI (Indonesian National Standard) 3753:2014 procedures. A total of $1-2 \mathrm{~g}$ of agarwood tea samples were weighed using analytical scales. Samples with known weight were then dried in an oven at $105^{\circ} \mathrm{C}$ for 3 hours. The sample was then placed in a desiccator to be cooled down before being weighed. The drying phase in the oven was repeated until the sample weight is constant (no weight loss again). The water content was calculated using the following formula:

Water Content $=\frac{W 1-W 2}{W 1-W 0} \times 100 \%$

Description:

W0 $=$ weight of an empty cups and its lid (g)

$\mathrm{W} 1$ = weight of the cup, its lid, and undried sample $(\mathrm{g})$

W2 = weight of the cup, its lid, and dried sample $(\mathrm{g})$

Total Phenol Analysis (Benites et al., 2015)

The total phenolic content of agarwood leaves tea sample solution was analyzed by using Folin-Ciocalteu method. The main process of this method is based on the phosphomolybdic-tungistic reduction with a phenolic hydroxyl group which will create a blue color. The measurement can be executed by absorbing its color (Musdholifah and Zubaidah, 2016). A total of $0.1 \mathrm{ml}$ of sample solution and $0.1 \mathrm{ml}$ of Folin-Ciocalteu $50 \%$ reagent were placed in the test tube. The solution was shaken by Vortex and added with 2 $\mathrm{ml}$ of $\mathrm{Na}_{2} \mathrm{CO}_{3}$ solution, and then it is incubated for 30 minutes in the dark condition. The absorbance of the solution was stamped by a spectrophotometer (Shimadzu UV mini 1240) at a wavelength of $765 \mathrm{~nm}$. The total phenol was calculated as gallic acid following the standard curve. Stock solution was made by dissolving gallic acid $25.5 \mathrm{mg} / 50 \mathrm{ml}(0.51$ $\mathrm{mg} / \mathrm{ml}$ or $510 \mathrm{ppm})$. Furthermore, it was diluted 10 times so that the concentration becomes $51 \mathrm{ppm}$, then a standard series with concentration of $0,10.2,20.4,30.6,40.8$, and $51 \mathrm{ppm}$ was prepared. The absorbance of each standard concentration was measured at $765 \mathrm{~nm}$ of wavelength. The absorbance was plotted into a standard curve until obtaining the regression 
equation. The research obtained the equation $y=0.0189 x-0.0023$. Thus, based on the equation, the total phenolic content can be calculated by the following formula:

Total phenol $(\mathrm{g} / 1000 \mathrm{~g})=\frac{(\mathrm{A} 765+0.0023) \times \mathrm{FP} \times \mathrm{V}}{0.0189 \times \mathrm{B}}$

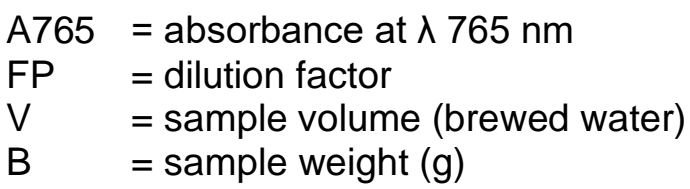

Antioxidant activity (Benites et al., 2015)

The sample solution was placed in a test tube with $0.1 \mathrm{ml}$ of volume for each and added with 1.5 DPPH (2,2-diphenyl-1-pycrylhydrazyl) $0.1 \mathrm{M}$ solution into methanol, then was shaken by Vortex for 2 minutes and incubated for 30 minutes. The existence of antioxidant activity caused the change of sample solution color into brownish-purple. The calculation of antioxidant activity was based on the reduction of the DPPH color which was measured using a spectrophotometer at $\lambda 517 \mathrm{~nm}$. Antioxidant activity value was determined by using a standard curve of vitamin $\mathrm{C}$. The standard solution was prepared by concentration of 25,50 , $100,200,400 \mu \mathrm{g} / \mathrm{ml}$, then it was measured using a spectrometer at $\lambda 517 \mathrm{~nm}$. A regression equation was generated at the standard curve of antioxidant was $y=0.0017 x+0.0145$. Hence, based on the regression equation, then the antioxidant activity of the sample can be calculated by the following formula:

Antioxidant activity $(\mu \mathrm{g} / \mathrm{g})=\frac{(\text { Abs B }- \text { Abs S }-0.0145) \times V}{0.0017 \times B}$

Abs $B=$ Blank Absorbance at $\lambda 517 \mathrm{~nm}$

Abs $S=$ Sample Absorbance at $\lambda 517 \mathrm{~nm}$

$\mathrm{V} \quad=$ sample volume (brewed water)

$\mathrm{B} \quad=$ sample weight $(\mathrm{g})$

Organoleptic Test

The organoleptic test of 9 samples (treatment) of agarwood tea was conducted by brewing 1 gram of tea powder into $100 \mathrm{ml}$ of boiled water with a serving size of $100 \mathrm{ml}$ for 5 panelists. The color and aroma testing were evaluated using the scoring test method, while the taste was tested using the hedonic test. The testing used 5 scores for each tested parameter. The description of each score depends on the parameter being tested. The testing involved 61 panelists that were chosen randomly in terms of age, gender, or profession. Panelists' ages range from 19 to 73 years old, with occupation as university students and employees (government and non-government employees). Every panelist was asked to give their impression on the color, aroma, and taste of the brewed agarwood tea. Furthermore, each panelist assessed according to his/her opinion based on the form provided. All panelists' opinion or impression was subsequently compiled or recapitulated into score table for each parameter and then the variance (ANOVA) was analyzed using software SPSS Version 25. 
Table 1. Scores of brewed aloe leaf tea

\begin{tabular}{llll}
\hline \multirow{2}{*}{ Score } & \multicolumn{3}{c}{ Description } \\
\cline { 2 - 4 } & \multicolumn{1}{c}{ Color } & \multicolumn{1}{c}{ Aroma } & \multicolumn{1}{c}{ Taste } \\
\hline 5 & Yellow & Highly fragrant & Very good \\
4 & Brownish yellow & Fragrant & Good \\
3 & Light brown & Rather fragrant & Rather good \\
2 & Almost dark brown & Not fragrant & Dislike \\
1 & Dark brown & Bad & Very dislike \\
\hline
\end{tabular}

\section{RESULT AND DISCUSSION}

1. Particle Size and Water Content

The size of the tea particle is an important parameter for a teabag. The tea particle is expected to be fine particle so that it provides good result to its brew. Therefore, multiple studies of teabag processing considered the particle size of tea in making its formulation. According to Putri (2012), the samples of mulberry tea, green tea, and dried stevia leaves milled into 8 mesh sizes to conform to SNI of a green tea bag's product standard. The sieving results in this study showed variety in the percentage of powder that passed the three different sieve sizes. The percentage of agarwood tea powder that passed 10, 20, and 80 mesh sieves did not show a specific pattern between treatments (Table 2).

Table 2. Percentage of agarwood tea powder that passed sieves; 10,20 , and 80 mesh

\begin{tabular}{|c|c|c|c|c|c|}
\hline \multirow[b]{2}{*}{ Treatment } & \multirow[b]{2}{*}{$\begin{array}{l}\text { Milled } \\
\text { Weight } \\
\text { (g) }\end{array}$} & \multicolumn{3}{|c|}{ Percentage of passing * } & \multirow[b]{2}{*}{$\begin{array}{l}\text { Water } \\
\text { Content } \\
(\%)\end{array}$} \\
\hline & & $\begin{array}{l}\text { Passing } \\
10 \text { Mesh } \\
(\%)\end{array}$ & $\begin{array}{l}\text { Passing } \\
20 \text { Mesh } \\
(\%)\end{array}$ & $\begin{array}{l}\text { Passing } 80 \\
\text { Mesh (\%) }\end{array}$ & \\
\hline Crassna-0 & 44.06 & 64.28 & 57.47 & 24.47 & $10.36 \mathrm{f}$ \\
\hline Crassna-70 & 39.89 & 78.87 & 70.44 & 19.10 & $9.70 \mathrm{~d}$ \\
\hline Crassna-90 & 46.69 & 77.45 & 68.92 & 20.48 & $9.47 \mathrm{c}$ \\
\hline Malaccensis -0 & 58.29 & 74.20 & 62.36 & 25.36 & $9.96 \mathrm{e}$ \\
\hline $\begin{array}{l}\text { Malaccensis- } \\
70\end{array}$ & 62.23 & 98.33 & 90.62 & 22.34 & $9.49 \mathrm{c}$ \\
\hline $\begin{array}{l}\text { Malaccensis- } \\
90\end{array}$ & 62.90 & 98.92 & 93.93 & 23.56 & $9.15 \mathrm{a}$ \\
\hline Subintegra-0 & 39.30 & 65.47 & 44.17 & 23.03 & $9.21 \mathrm{~b}$ \\
\hline Subintegra-70 & 42.77 & 38.74 & 31.61 & 15.60 & $12.37 \mathrm{~g}$ \\
\hline Subintegra-90 & 39.74 & 85.00 & 78.89 & 28.69 & $9.17 \mathrm{a}$ \\
\hline Description: & \multicolumn{5}{|c|}{$\begin{array}{l}\text { The numbers followed by different letters in the same column } \\
\text { show significant differences }(P<0.05) \text {. } \\
\text { * percentage of milled weight. }\end{array}$} \\
\hline
\end{tabular}

The maximum water content according to the national standard of black tea bag with code SNI 3753-2014 is 10\% (BSN, 2014). This differs from the standard of green tea with code SNI 3945-2016 (BSN, 2016) and packaged-dry tea with code SNI 01-3836-2000 (BSN, 2000) which are respectively $8 \%$. In this research, the water content of tea powder varied from $9 \%$ to $12 \%$. These results were mostly less than $10 \%$, so that it achieved to the national standard for black tea bags.

The particle size can be influenced by its water content. In this research, Subintegra70 minute has the lowest percentage of passing but also has the highest water content (Table 2). Our finding showed that the water content negatively correlated with percentage of passing by mesh 10 sieve with correlation coefficient (R2) of 0.68 (Figure 1). The results 
suggest that the highwater content caused the difficulty to crush the leaves into small particles.

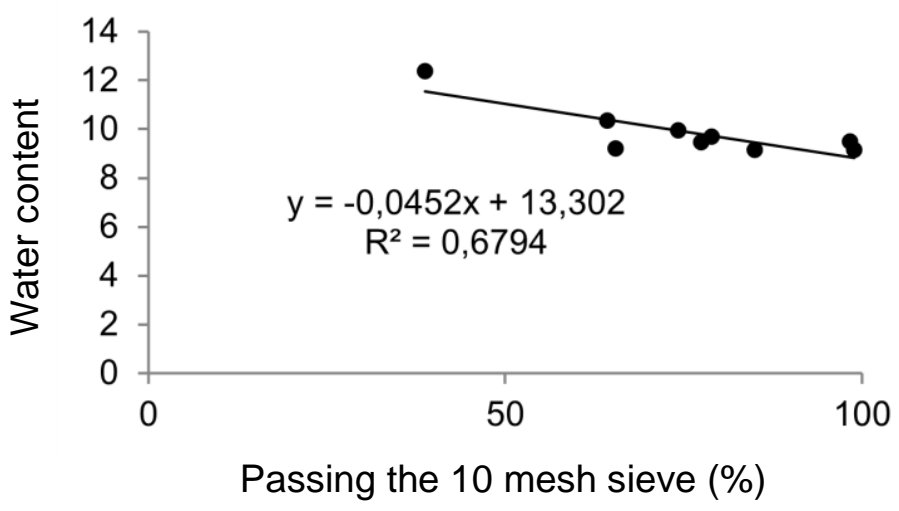

Figure 1. Correlation between passing percentage of 10 mesh sieve and water content

\section{Total Phenol and Antioxidant Activity}

Types of plants and the duration of fermentation affect the total phenol. The leaves powder of $A$. subintegra contained the highest total phenol, whereas $A$. crassna had the lowest phenol. The fermentation time has a significant influence on the total phenol content of three kinds of Aquilaria plants. The phenol content of every kind of Aquilaria was increased by the longer fermentation time (Table 3).

Table 3. Total phenol of Aquilaria leaves powder at three fermentation time

\begin{tabular}{ccccc}
\hline \multirow{2}{*}{$\begin{array}{c}\text { Time } \\
\text { (minute) }\end{array}$} & A. crassna & A. malaccensis & A. subintegra & Average \\
\hline 0 & $1386.10 \mathrm{a}$ & $2672.82 \mathrm{a}$ & $3028.29 \mathrm{a}$ & $2362.40 \mathrm{a}$ \\
70 & $2061.23 \mathrm{~b}$ & $2761.98 \mathrm{~b}$ & $4361.72 \mathrm{~b}$ & $3061.64 \mathrm{~b}$ \\
90 & $2304.79 \mathrm{c}$ & $2967.97 \mathrm{c}$ & $4397.20 \mathrm{c}$ & $3223.32 \mathrm{c}$ \\
\hline
\end{tabular}

Description: The numbers followed by different letters in the same column show significant differences $(\mathrm{P}<0.05)$.

Based on the results, Aquilaria leaves had a significant effect on the antioxidant content. The tea powder of A.subintegraleaves had the highest antioxidant, while $A$. crassna had the lowest. The fermentation time also significantly affects antioxidant activity. The results demonstrate that the longer duration of fermentation increasing the antioxidant activity. The increase of enzymatic oxidation duration to 70 and 90 minutes escalated the antioxidant activity of $A$. crassna and $A$. Malaccensis leaves powder significantly. $A$. subintegra was also increased but not in a significant manner (Table 4). At the treatment of 0 minutes, the antioxidant activity of $A$. Subintegra was high; it was indeed over the antioxidant activity of $A$. crassna dan $A$. malaccensis at the treatment of 70 and 90 minutes.

The pattern of antioxidant activity is equal to the pattern of total phenolic content. In terms of plant species, $A$. Subintegra produced the highest total phenol and antioxidant activity, while $A$. Crassna produced the lowest. On the other hand, the longer the fermentation time, the higher value of the antioxidant activity and total phenol produced. A good correlation between antioxidants and total phenols is shown by the value of appreciable correlation coefficient (R2) that is 0.8 (Figure 2). 
Table 4. Antioxidant activity of Aquilaria leaf powder at three fermentation times

\begin{tabular}{ccccc}
\hline \multirow{2}{*}{ Time (minute) } & \multicolumn{4}{c}{ Antioxidant (mg/1000g) } \\
\cline { 2 - 5 } & A. crassna & A. malaccensis & A. subintegra & Average \\
\hline 0 & $15502.27 \mathrm{a}$ & $28872.15 \mathrm{a}$ & $43871.20 \mathrm{a}$ & $29415.21 \mathrm{a}$ \\
70 & $26199.55 \mathrm{~b}$ & $29977.35 \mathrm{~b}$ & $44347.77 \mathrm{a}$ & $33508.22 \mathrm{~b}$ \\
90 & $32268.22 \mathrm{C}$ & $31234.80 \mathrm{c}$ & $44472.02 \mathrm{a}$ & $35991.68 \mathrm{c}$ \\
\hline
\end{tabular}

Description: The numbers followed by different letters in the same column show significant differences $(\mathrm{P}<0.05)$.

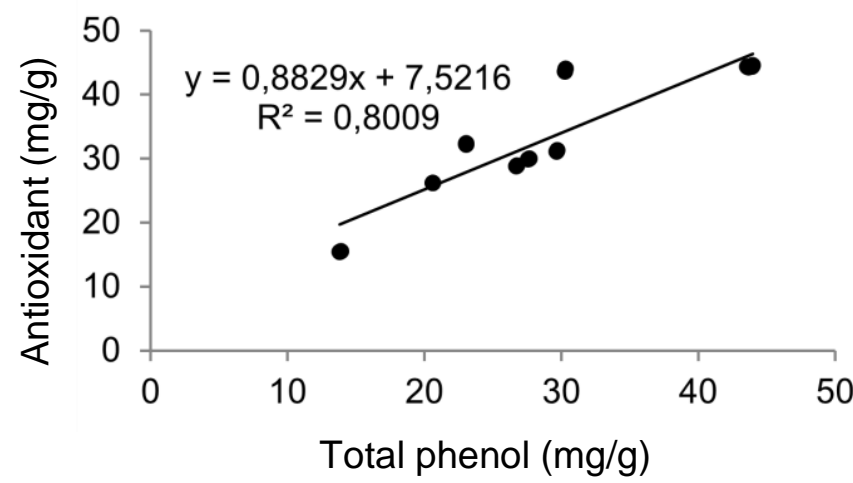

Figure 2. Correlation between antioxidant and total phenol

The antioxidant content in tea is a phenolic component that is called polyphenols. It has many hydroxyl groups $(-\mathrm{OH})$ that contribute its electron to act as an antioxidant. Moreover, antioxidant has a major role to scavenge free radicals (Hartoyo, 2003). A tea leaf kneading caused the release of polyphenol oxidase enzyme to change polyphenol into oxidized polyphenol form. The changes of polyphenols due to the oxidation caused the decrease of performance of polyphenols as an antioxidant. Catechins are the dominant polyphenols in the tea leaves before its fermented. In the fermentation process (enzymatic oxidation), the catechins can turn into oxidized polyphenol compounds such as theaflavins. Thus, theaflavin compounds have lower antioxidant activity than catechins (Subangkit, 2015).

The length of fermentation time affects the content of theaflavins and thearubigins. The theaflavin levels in black tea were decreased, while thearubigin levels increased were followed by the increasing of fermentation time from 30 to 120 minutes (Asil, Rabiei, and Ansari, 2012). The quality of black tea is related to its catechin contents. Black tea extract quality 1 (Broken Orange Pekoe/BOP), quality 8 (Broken Pekoe/BP2), and quality 15 (BBL) have different catechins content with a concentration of $18.29 \mathrm{ppm}, 18.05$, and 12.29 respectively (Hasanah, Hamdani, and Firmansyah, 2012). Cathecins are water-soluble, colorless, and provide a bitter and sour brewed tea. Cathecins compound plays a significant role in determining tea quality. Therefore, cathecins are frequently modified to attempt the best quality tea in terms of taste, color, and aroma (Hartoyo, 2003). However, based on the result of the research on various tea products circulating in Europe and the United States of America, the findings are concluded that the total capacity of antioxidant of the tea does not relate with one type of polyphenol such as catechins, yet it is a combination of various antioxidants including phenolic acid and polyphenol (Lee et al., 2002).

It has been reported that the antioxidant content of various tea products (Camelia sinensis) decreased after experiencing enzymatic oxidation. Antioxidant activity of different tea commercial products of Camelia sinensis leaf is lower than green tea (Lee et al., 2002). Black tea made from leaves other than Camelia sinensis such as Coleus amboinicus also has smaller antioxidant content than green tea (Rahayu, Jose, \& Haryani, 2015). 
This research showed contrarily that the antioxidant content of agarwood tea was increased following the fermentation. According to the research, the result included the effect of length of fermentation on the quality of soursop leaf tea. Soursop leaf (Annona muricate L.) which is fermented for 1,2,3 and 4 hours, has antioxidant activities of $9,16,20$, and 29 ppm respectively (Tanjung, Hamzah, and Efendi, 2016). Polyphenol and antioxidant content of bush tea (Athrixia phylicoides) are significantly increased by increasing the length of fermentation. The polyphenol level of bush tea was $3.4 \mathrm{mg} / 100 \mathrm{mg}$ at 0 minutes and 4.4 $\mathrm{mg} / 100 \mathrm{mg}$ at 90 minutes, while antioxidant level was $8.3 \mu \mathrm{mol} / \mathrm{g}$ at 0 minutes, $8.8 \mu \mathrm{mol} / \mathrm{g}$ at 90 minutes, and $8.6 \mu \mathrm{mol} / \mathrm{g}$ at 120 minutes (Hlahla, Mudau, and Mariga, 2010).

\section{Organoleptic Test}

Organoleptic test involving 61 panelists produced a brew with a significant difference of color and taste, but the aroma was not significantly different (Table 5). The treatment at 0 minutes provided different colors compared to the brewed water for 70 and 90 minutes on the three types of Aquilaria. Among the treatment of 70 and 90 minutes, it is the same for each plant, yet it is different between plants. A. subintegra leaf tea which was fermented for 70 and 90 minutes had the darkest color namely almost dark brown. The lightest color of a brew was showed by $A$. subintegra-0 minute with 1.52 of average score and having color between yellow and yellow-brownish.

Table 5. Result of organoleptic test

\begin{tabular}{lccc}
\hline \multicolumn{1}{c}{ Treatment } & Brew color & Brew aroma & Brew taste \\
\hline Crassna-0 minute & $2.33 \mathrm{c}$ & 2.98 & $3.33 \mathrm{~d}$ \\
Crassna-70 minutes & $2.70 \mathrm{~d}$ & 3.15 & $3.33 \mathrm{~d}$ \\
Crassna-90 minutes & $3.07 \mathrm{~d}$ & 3.21 & $3.23 \mathrm{~cd}$ \\
Malaccensis-0 minutes & $1.92 \mathrm{~b}$ & 2.85 & $3.07 \mathrm{bcd}$ \\
Malaccensis-70 minutes & $2.77 \mathrm{~d}$ & 3.08 & $2.90 \mathrm{bc}$ \\
Malaccensis-90 minutes & $2.82 \mathrm{~d}$ & 3.05 & $2.87 \mathrm{~b}$ \\
Subintegra-0 minute & $1.52 \mathrm{a}$ & 3.16 & $1.44 \mathrm{a}$ \\
Subintegra-70 minutes & $3.59 \mathrm{e}$ & 3.25 & $1.34 \mathrm{a}$ \\
Subintegra-90 minutes & $3.64 \mathrm{e}$ & 3.15 & $1.30 \mathrm{a}$ \\
\hline
\end{tabular}

Taste is an important criterion for the consumer. Our findings show interesting results where the significant difference between samples did not occur in the length of fermentation but its type of plant. $A$. Crassna leaf tea obtained average score of 3 , which is in the category of "rather good". A. subintegra leaf tea, on the contrary, obtained an average score of 1 , which is in the category of "Very dislike". Table 6 shows most of the panelists stated "dislike" to the A. subintegra leaf tea. The taste dislike was related to the high total phenolic content. Thus, $A$. Subintegra has the highest total phenol, twice as much compared to as $A$. crassna (Table 3). 
Table 6. Panelists' assessment on contentment to the agarwood tea

\begin{tabular}{lcccccc}
\hline \multicolumn{1}{c}{ Type of tea } & $\begin{array}{c}\text { Very } \\
\text { dislike }\end{array}$ & Dislike & $\begin{array}{c}\text { Rather } \\
\text { good }\end{array}$ & Good & $\begin{array}{c}\text { Very } \\
\text { good }\end{array}$ & $\begin{array}{c}\text { Total } \\
\text { Panelist } \\
\text { (61 people) }\end{array}$ \\
\hline Crassna-0 & $0 \%$ & $20 \%$ & $36 \%$ & $36 \%$ & $8 \%$ & $100 \%$ \\
Crassna-70 & $3 \%$ & $21 \%$ & $25 \%$ & $41 \%$ & $10 \%$ & $100 \%$ \\
Crassna-90 & $8 \%$ & $10 \%$ & $39 \%$ & $36 \%$ & $7 \%$ & $100 \%$ \\
Malaccensis-0 & $10 \%$ & $20 \%$ & $26 \%$ & $43 \%$ & $2 \%$ & $100 \%$ \\
Malaccensis-70 & $8 \%$ & $34 \%$ & $23 \%$ & $28 \%$ & $7 \%$ & $100 \%$ \\
Malaccensis-90 & $8 \%$ & $21 \%$ & $46 \%$ & $25 \%$ & $0 \%$ & $100 \%$ \\
Subintegra-0 & $64 \%$ & $28 \%$ & $8 \%$ & $0 \%$ & $0 \%$ & $100 \%$ \\
Subintegra-70 & $77 \%$ & $16 \%$ & $3 \%$ & $2 \%$ & $2 \%$ & $100 \%$ \\
Subintegra-90 & $79 \%$ & $15 \%$ & $5 \%$ & $2 \%$ & $0 \%$ & $100 \%$ \\
\hline
\end{tabular}

\section{CONCLUSION}

The outcome of various treatment lead conclusion that total phenolic and antioxidant content of agarwood leaf tea have been influenced by the type of plant and fermentation length (enzymatic oxidation). The total phenol also has a positive correlation to the antioxidant activity of agarwood leaf tea. The most liked type of plant for agarwood tea is $A$. Crassna, with the length of fermentation of 70 minutes. Hence, a tea with lower phenolic content is preferable compared to those with high phenolic content.

\section{REFERENCES}

Adam, A. Z., Lee, S. Y., \& Mohamed, R. (2017). Pharmacological Properties of Agarwood Tea Derived from Aquilaria (Thymelaeaceae) leaves: An Emerging Contemporary Herbal Drink. Journal of Herbal Medicine, 10, 37-44. https://doi.org/10.1016/j.hermed.2017.06.002

Anggraini, T. (2017). Proses dan Manfaat Teh. https://doi.org/10.25077/car.41.38

Asil, M. H., Rabiei, B., \& Ansari, R. H. (2012). Optimal Fermentation Time and Temperature to Improve Biochemical Composition and Sensory Characteristics of Black Tea. Australian Journal of Crop Science, 6(3), 550-558.

Benites, R., Formagio, A., Argandoña, E., Volobuff, C., Trevizan, L., Vieira, M., \& Silva, M. (2015). Contents of Constituents and Antioxidant Activity of Seed and Pulp Extracts of Annona Coriacea and Annona Sylvatica. Brazilian Journal of Biology, 75(3), 685-691. https://doi.org/10.1590/1519-6984.21313

Bizzy, I., Faisal, M., \& Setiabudidaya, D. (2011). Studi Potensi Energi Matahari dalam Perancangan Peralatan Pelayuan dan Pengeringan Pucuk Daun Gaharu. Prosiding Seminar Nasional AVoER Ke-3, 62-68. Palembang: Universitas Sriwijaya.

Blanchette, R., \& Beek, H. van. (2001). Patent No. US6848211B2. United States.

BSN. Teh Kering dalam Kemasan. , Pub. L. No. SNI 01-3836-2000 (2000).

BSN. Teh Hitam Celup. , Pub. L. No. SNI 3753:2014, 34 (2014).

BSN. Teh Hijau. , Pub. L. No. SNI 3945-2016, 21 (2016).

Hartoyo, A. (2003). Teh dan Khasiatnya bagi Kesehatan Sebuah Tinjauan IImiah. Yogyakarta: Kanisius.

Hasanah, S. U., Hamdani, S., \& Firmansyah, A. (2012). Perbandingan Kadar Katekin dari Beberapa Jenis Kualitas Teh Hitam (Camellia sinensis L.[O] Kuntze) di Pusat Penelitian Teh dan Kina (PPTK) Gambung. Jurnal Sains Dan Teknologi Farmasi Indonesia, 1(1).

Hlahla, L. N., Mudau, F. N., \& Mariga, I. K. (2010). Effect of Fermentation Temperature and Time on The Chemical Composition of Bush Tea (Athrixia phylicoides DC.). Journal of Medicinal Plants Research, 4(9), 824-829. https://doi.org/10.5897/JMPR10.118 
Lee, K. W., Lee, H. J., \& Lee, C. Y. (2002). Antioxidant Activity of Black Tea vs. Green Tea. The Journal of Nutrition, 132(4), 785. https://doi.org/10.1093/jn/132.4.785

Musdholifah, \& Zubaidah, E. (2016). Studi Aktivitas Antioksidan Kefir Teh Daun Sirsak dari Berbagai Merk di Pasaran. Jurnal Pangan Dan Agroindustri, 4(1), 29-39.

Nasution, P. A., Batubara, R., \& Surjanto, S. (2015). Tingkat Kekuatan Antioksidan Dan Kesukaan Masyarakat Terhadap Teh Daun Gaharu (Aquilaria Malaccensis Lamk) Berdasarkan Pohon Induksi Dan Non-induksi. Peronema Forestry Science Journal, 4(1), 10-21.

Putri, A. R. (2012). Formulasi Teh Celup Campuran Teh Hijau (Camellia Sinensis)-Murbei (Morus Alba)-Stevia (Stevia Rebaudiana) serta Pengaruhnya Terhadap Aktivitas Antioksidan. Bogor Agricultural University (IPB).

Rahayu, F., Jose, C., \& Haryani, Y. (2015). Total Fenolik, Flavonoid, Dan Aktivitas Antioksidan Dari Produk Teh Hijau Dan Teh Hitam Tanaman Bangun-bangun (Coleus Amboinicus) Dengan Perlakuan Ett Rumput Paitan. Jurnal Online Mahasiswa Fakultas Matematika Dan Ilmu Pengetahuan Alam Universitas Riau, 2(1), 170-177.

Rahmadini, F. (2015). Pengaruh Letak Daun dan Lama Fermentasi terhadap Mutu Teh Daun Gaharu. Universitas Sumatera Utara.

Subangkit, N. (2015). Teh Hitam atau Teh Hijau. Retrieved from https://www.kompasiana.com/nsubangkit/550b43c8a333119c1e2e3c64/teh-hitam-atauteh-hijau

Tanjung, R., Hamzah, F., \& Efendi, R. (2016). Lama Fermentasi terhadap Mutu Teh Daun Sirsak (Annona Muricata L.). Jurnal Online Mahasiswa Fakultas Pertanian Universitas Riau, 3(2), 1-9.

Wyn, L. T., \& Anak, N. A. (2010). Wood For Trees: A Review of the Agarwood (Gaharu) Trade in Malaysia. Selangor. 